\title{
KEHAMILAN HETEROTROPIC DENGAN DISERTAI SYOK HIPOVOLUMIK
}

\author{
Mochamad Ma'roef \\ Fakultas Kedokteran Universitas Muhammadiyah Malang \\ Rumah Sakit Muhammadiyah Lamongan \\ email : rufiz_70@yahoo.com
}

\begin{abstract}
Abtrak
Latar Belakang: Kehamilan heterotopic mengacu pada kehamilan yang terjadi bersamaan di dua lokasi implantasi yang berbeda, mayoritas terjadi di tuba falopii. Penyebab pasti tidak jelas, tetapi kehamilan ganda dengan kombinasi dari kehamilan intrauterin dan ekstrauterin adalah faktor risiko untuk setiap kesatuan harus ditangani.

Presentasi kasus: Pasien usia 34 tahun hamil 17 minggu, keluhan penurunan kesadaran, dan sebelumnya pasien mengeluh nyeri perut setelah BAK. Mengalami perdarahan dari jalan lahir 1 minggu yang lalu berlangsung selama 4 hari. Tensi 76/43 mmHg, Nadi 97 x/m, Suhu 36.6 C, RR 24 x/m, SaO2 96 \% tanpa O2. Pasien mengalami penurunan kesadaran (delirium),anemis, abdomen distended, defans muscular +, nyeri tekan +, akral dingin kering pucat. Teraba benjolan di labia mayor dekstra. Pemeriksaan laboratorium didapatkan Hb 7, Hct 37, Lekosit: 10.400, Trombosit 283.000, HbsAg negatif, Clorida serum 105, Kalium Serum 3,7, Natrium Serum 138, GDA 119, Diffcount 4/1/80/11/4, LED 64/ 86.

Pembahasan: Diagnosis pasti adalah kehamilan heterotropik. Tatalaksana pasien adalah laparotomi, dengan kondisi adanya perdarahan intraabdominal yang cukup masif. Laporan operasi menyebutkan adanya kehamilan ekstrauterine dan intrauterine dengan usia kehamilan yang berbeda.Masih menjadi tanda tanya besar adalah bagaimana terjadinya kehamilan intra dan ekstra uterine dalam usia kehamilan yang berbeda.

Kesimpulan: Diagnosis KET + G1 P0000 A000 UK 19 minggu + IUFD + Syok hypovolemik. Ditemukan kejadian rupturnya kehamilan ektopik yang terjadi saat usia kehamilan 17 minggu, dengan kemungkinan bahwa usia kehamilan antara kehamilan intra dan ekstra uterine ini berbeda.
\end{abstract}

Kata kunci: kehamilan heterotropik, KET, IUFD, syok hipovolemik, kehamilan ekstrauterine, kehamilan intrauterine 


\section{Abtract}

Background: Heterotopic pregnancy refers to a pregnancy that occurred simultaneously in two different implantation site. The majority occur in the fallopian tube. The exact cause s not clear, but the combination of multiple pregnancy with intrauterine and extrauterine pregnancy, a risk factor for all entities must be addressed.

Case presentation: A female 34 year old 17 weeks pregnant, complaints of loss of consciousness, and before the patient complains of abdominal pain after a bowel movement. Experienced bleeding from vagina a week ago lasted for 4 days. Blood pressure 76/43 mmHg, heart rate $97 \mathrm{x} / \mathrm{m}$, temperature $36.6 \mathrm{C}$, respiratory rate $24 \mathrm{x} / \mathrm{m}, \mathrm{SaO} 296 \%$ without O2. Loss of consciousness (delirium), looked anemic, distended abdomen, muscular defans + , tenderness + , pale, dry, and cold on the extrimities. Palpable lump in the labia majora dekstra. Laboratory tests obtained Hb 7, HCT 37, leukocytes: 10.400, Platelets 283,000, HBsAg negative, serum Cloride 105, 3.7 Serum Potassium, Sodium Serum 138, GDA 119, Diff count 4/1/80/11/4, LED 64 / 86.

Discussion: A definitive diagnosis is heterotopic pregnancy. Management of the case was a laparotomy, with the condition of the intra-abdominal bleeding is massive enough. Report found that extrauterine and intrauterine pregnancy with differentgestational age. There was still a big question mark is how the intra and extra uterine pregnancy in differentgestational age.

Conclusion: Diagnosis wasectopic pregnancy + G1 P0000 A000 19 weeks + IUFD + hypovolemic shock. Found the incidence of ruptured ectopic pregnancy occurs when the gestational age of 17 weeks, with the possibility that the gestational age between intra and ekstrauterine pregnancy is different.

Keywords: heterotropic pregnancy, ectopic pregnancy, IUFD, hypovolemic shock, ekstrauterine pregnancy, intrauterine pregnancy.

\section{KASUS}

Pada tanggal 5 April 2014. Wanita, usia 34 tahun datang ke Unit Gawat Darurat RS Muhamadiyah Lamongan dengan keluhan penurunan Kesadaran. Pasien datang ke IGD dengan keluhan penurunan kesadaran sejak 2 jam SMRS. Lemas (+), Pasien tibatiba nyeri perut setelah buang air kecil 2,5 jam SMRS. Pasien sedang hamil 17 minggu. Sebelum pingsan pasien batuk pilek selama dua hari yang lalu. Batuk berdahak berwarna bening. Riwayat perdarahan dari jalan lahir 1 minggu yang lalu, Perdarahan seperti mens selama 4 hari. Saat perdarahan kadang kadang mengeluh nyeri perut. RPD : Asma -, Alergi udara dingin, Riwayat operasi usus buntu . HPHT : 12 November 2013.

\section{PEMERIKSAAN FISIK}

Vital sign :

$\begin{array}{ll}\text { TD } & : 76 / 43 \mathrm{mmHg} \mathrm{N}: 97 \mathrm{x} / \mathrm{m} \mathrm{T} \quad: 36.6 \mathrm{C} \\ \mathrm{RR} & : 24 \mathrm{x} / \mathrm{m}\end{array}$

Primary Survey

A : Clear, gargling (-), Snoring (-), Speak Fluently +, Potensial Obstruksi - 
B : Spontan , RR : 24 x/menit, Ves/ves, Rh -/-, Wh -

/- SaO2 $96 \%$ tanpa O2

C : Akral HKM , CRT 3, TD : 76/43, N : 97 x/m, lemah

Secondary Survey

Delirium Gelisah

K/l : a+/i-/c-/d-Tho : Sim, Retraksi -/-C : S1 S2 Tunggal , Mur mur -, Galop -P : Ves/ves, Wh -/- Rh -/- .Abd : Distended +, Defans Muscular +, Nyeri tekan + , H/l Ttb,Eks : akral DBP

\section{PEMERIKSAAN PENUNJANG}

HB: 7 Hct $\quad$ : 37 Lekosit $\quad$ : 10.400 Trombosit : 283.000 HbsAg: Negatif, Clorida serum 105, Kalium Serum: 3,7, Natrium Serum: 138, GDA : 119, Diff: 4/1/80/11/4 LED : 64/86

UltraSonoGrafi kesimpulan : kehamilan intra uteri usia sekitar 19 minggu 4 hari , yang mengalami IUFD + internal bleeding yang banyak, curiga ruptur uteri ?

Diagnosa

KET

G1 P0000 A000 Uk 19 minggu + IUFD

Syok hypovolemik

Manajemen:

Dilakukan tindakan Laparotomi dan didapatkan perdarahan intra abdomen dan Kehamilan Tuba yang sudah Pecah. Dilakukan pemeriksaan Hitopatologi. Uterus membesar sesuai kehamlan 18-20 minggu.

Hasil Pemeriksaan Histopatologi :

Kesimpulan : KEHAMILAN TUBA RUPTURE

\section{KAJIAN TEORI}

\section{Heterotropic Pregnancy}

\section{Definisi}

Kehamilan heterotopic mengacu pada adanya kehamilan yang terjadi bersamaan di dua lokasi implantasi yang berbeda. Paling sering keadaan kehamilan ini adalah kehamilan dari intrauterin dan kehamilan ektopik, bukan dua kehamilan ektopik. Mayoritas kehamilan ektopik terjadi di tuba falopi (90 persen); Namun, implantasi di leher rahim, ovarium, interstitial (kornu) segmen tuba, perut, dan sebelumnya bekas luka caesar telah dilaporkan juga menjadi tempat dari kehamilan ektopik ini.

\section{Epidemiologi}

Kejadian kehamilan heterotopic diperkirakan tergantung pada tingkat angka kejadian kehamilan ektopik dan keadaa kembar dizigot. kehamilan heterotopic seharusnya jarang terjadi bahkan sangat langka, diperkirakan terjadi pada 1 dari 30.000 kehamilan. Dengan munculnya teknik reproduksi yang dibantu (Assisted reproduction technique-ART), termasuk super-ovulasi, inseminasi intrauterine, dan fertilisasi in vitro, angka kejadian kehamilan heterotopic telah meningkat menjadi sekitar 1 di 3900 kehamilan. Sebuah analisis dari seluruh kehamilan ART yang terdata di Amerika Serikat tahun 1999-2002 melaporkan kejadian kehamilan heterotopic 1,5 per 1000 kehamilan ART.

Insiden kejadian kehamilan heterotopic akan meningkat terkait dengan tingginya proporsi pasien dengan penyakit tuba, serta tingginya tingkat estradiol dan progesteron, atau tingginya jumlah embrio yang ditransfer atau oosit berovulasi pada populasi. Faktorfaktor lain, seperti volume dan viskositas dari medium transfer dan teknik transfer embrio, juga mungkin memainkan peran. Sebuah riwayat penyakit radang panggul juga telah dikutip sebagai faktor predisposisi untuk kehamilan heterotopic.

Insidensi kehamilan heterotopik spontan dilaporkan berbagai dalam literatur. Bahwa kehamilan heterotopik, menurut definisi, kehamilan ganda dengan kombinasi 
kehamilan intrauterin dan ekstrauterin, kejadian tergantung pada kejadian masing-masing komponen.

De Voe dan Pratt menghitung gambaran teoritis menggunakan insiden kehamilan ektopik tersebut, 0,37\%, dikalikan dengan tingkat kehamilan kembar fraternal, 0,8\%. Hasil perhitungan ini adalah 0,003\%. Namun, mereka melaporkan dua kasus di antara 13.527 kelahiran di Mayo Clinic pada tahun 1947, insidensinya $0,015 \%$.

Pada tahun 1982, Richards,dkk melakukan perhitungan yang sama seperti De Voe dan Pratt dan ditentukan insidensinya 0,0064\%, atau 1/15 dari 600 kehamilan, menggunakan insidensi kehamilan ektopik pada saat itu seperti yang dijelaskan oleh Kitchin,dkk. Pada tahun 1990, Molloy, dkk melakukan 6204 siklus IVF / transfer gamet intra fallopi (GIFT) yang menghasilkan 1001 kehamilan, sepuluh di antaranya merupakan kehamilan heterotopik, untuk insidensi 1\%. Dalam tahun yang sama, Dimitry,dkk melaporkan 1.996 siklus IVF dari

periode 1984-1988 yang menghasilkan 315 kehamilan, sembilan di antaranya merupakan kehamilan heterotopik, untuk insidensi 2,9\%. Tak lama kemudian, Dor,dkk menjelaskan 4/428 kehamilan heterotopik (0,9\%) setelah 2624 siklus IVF selama periode 9,5 tahun. Singkatnya, kejadian diperkirakan kehamilan heterotopik berkisar dari 1-2/30 000 pada populasi umum sampai 1/100 dengan ART

\section{Faktor Resiko}

Penyebab yang pasti dari kehamilan heterotopik tidak jelas, tetapi kehamilan ganda dengan kombinasi dari kehamilan intrauterin dan ekstrauterin, faktor risiko untuk setiap kesatuan harus ditangani. Kehamilan ektopik paling sering dikaitkan dengan kerusakan tuba dan transportasi embrio yang berubah. Adanya kelainan tuba, yang umumnya dihasilkan dari operasi sebelumnya, infeksi panggul, dan endometriosis, merupakan faktor risiko terkuat untuk kehamilan ektopik.

Riwayat pembedahan pada tuba membawa risiko tertinggi untuk kehamilan ektopik, terutama jika operasi itu dilakukan untuk kehamilan ektopik sebelumnya atau untuk sterilisasi. Merokok, peningkatan insidensi penyakit menular seksual mengakibatkan salfingitis dan kemanjuran terapi antibiotik dalam mencegah oklusi tuba total setelah episode salfingitis terkait dengan meningkatnya insidensi kehamilan ektopik pada umumnya, dan khususnya kehamilan heterotopik.

Faktor risiko yang menyebabkan kehamilan ganda sangat penting dalam pembahasan etiologi dari kehamilan heterotopik. Tidak diragukan lagi, faktor yang paling signifikan adalah tingginya insidensi kehamilan kembar setelah penatalaksanaan fertilitas, dengan rata- rata 5-10\%, 10-30\% dan 35\% mengikuti klomifen sitrat, gonadotropin dan IVF, secara berurutan. Glassner,dkk menggambarkan dua kasus kehamilan heterotopik pada pasien yang diterapi dengan klomifen sitrat, dan menyimpulkan bahwa kejadian kehamilan heterotopik adalah 1/900 kehamilan setelah terapi. Berger dan Taymor sebelumnya menjelaskan dua kasus kehamilan heterotopik, pertama, setelah pengobatan dengan klomifen sitrat, dan yang kedua setelah pengobatan dengan gonadotropin. Kedua pasien menjalani laparotomi dan salfingektomi untuk kehamilan ektopik yang ruptur, dan kedua kehamilan intrauterin berlangsung sampai aterm, menghasilkan persalinan bayi yang sehat. Selama periode 5 tahundi mana kedua kasus diamati, 204 kehamilan dihasilkan dari penggunaan klomifen sitrat ataugonadotropin, menghasilkan kejadian 1/100 pada studi kecil.Bahwa terapi IVF merupakan faktor risiko utama untuk kehamilan ganda sertakehamilan ektopik, dapat dibayangkan bahwa IVF menyebabkan peningkatan insidensikehamilan heterotopik, terutama mengingat bahwa IVF dikembangkan untuk mengatasi infertilitas mekanik, dimana kelainan tuba merupakan faktor risiko independen untuk kehamilan ektopik.

Knopman dkk, melaporkan kehamilan heterotopik abdominal setelah transfer dari dua blastokista. Keguguran intrauterin terjadi pertama dan ruptur kehamilan abdominal dua minggu kemudian dan ektopik di angkat dengan laparoskopi. Kehamilan ektopik menjadi lebih rendah secara signifikan pada transfer blastokista frozen- thawed tunggal dibandingkan dengan dua blastokista.

Goldman,dkk meninjau 34 kehamilan heterotopik yang mengikuti terapi IVF yang dipublikasikan antara tahun 1985 dan 1991. Beberapa faktor predisposisi 
berhubungan dengan teknik transfer embrio, jumlah dan kualitas embrio yang ditransfer, lingkungan hormonal dan kemungkinan untuk superfekundasi.

Insersi yang dalam dari kateter transfer ke kavum uteri dapat menyebabkan embrio bermigrasi dari orifisium uterotubal, di mana mereka disimpan, ke dalam tuba. Insersi kateter transfer ke dalam pertengahan kavum uteri dapat membantu menghindari migrasi. Embrio bermigrasi ke dalam tuba juga dapat difasilitasi oleh gravitasi karena menggunakan posisi Trendelenburg.

Sebuah media yang lengket, kental dan berat (sejumlah besar serum manusia) yang digunakan pada beberapa sentra untuk transfer embrio juga dapat menyebabkan migrasi embrio ke dalam tuba.Sejumlah besar media transfer juga dapat memfasilitasi migrasi embrio ke dalam tuba. Membatasi jumlah media transfer menjadi 10-20 $\mu$ l dapat membantu untuk menghindariimplantasi ektopik, walaupun kehamilan heterotopik dapat terjadi dengan volume kurangdari $10 \mu \mathrm{l}$.

Kehamilan heterotopik terjadi setelah transfer 2-6 embrio. Peran patogenisitas dari jumlah embrio tidak jelas. Transfer satu embrio hanya menghilangkan kemungkinan untuk kehamilan heterotopik. Kualitas embrio juga mungkin faktor penyebabnya, meskipun kehamilan heterotopik digambarkan setelah mentransfer embrio frozen-thawed, menunjukkan bahwa bahkan embrio dapat tertanam dalam tuba fallopi.

Superfekundasi dapat terjadi jika pasien dengan tuba paten menjalani terapi IVF. kehamilan ektopik / heterotopik mungkin berasal dari pembuahan spontan dari sebuah oosit yang belum pulih, jika senggama terjadi dekat dengan waktu ovulasi pengaruh berbagai hormon, termasuk hormon seks steroid, pada motilitas tuba telah dipelajari. Beberapa penulis menyatakan peran kadar estrogen yang tinggi tepat sebelum pengambilan ovum dalam patogenesis kehamilan ektopik. Namun, laporan kehamilan heterotopik selama siklus non-stimulasi, ketika embrio yang ditransfer baik setelah ovulasi spontan atau membangun endometrium yang disinkronkan dengan terapi pengganti estrogen- progesteron yang terkontrol, tidak mendukung konsep ini.

\section{Manifestasi klinis}

Manifestasi klinis kehamilan heterotopic mirip dengan gejala threarened abortion dan kehamilan ektopik. Gejalanya antara lain termasuk sakit perut, massa di adneksa, iritasi peritoneal, dan rahim yang membesar. Pasien-pasien ini sering didiagnosis pada usia kehamilan lebih lanjut (misalnya, 16 minggu ) dari kehamilan tuba terisolasi karena ketika kehamilan intrauterin diamati pada USG, kemungkinan adanya kehamilan ektopik umumnya tidak dianggap oleh pemeriksa. Mengingat potensi tinggi untuk misdiagnosis, ada insiden tinggi pecahnya tuba. Pecahnya tempat dari implantasi kehamilan ektopik akan menyebabkan nyeri perut yang sangat (akut abdomen) dan syok hemodinamik.

Gejala pada pasien KET :

1. Nyeri \% Nyeri panggul atau abdomen hampir selalu terdapat.

- Nyeri dapat bersifat unilateral atau bilateral ; terlokalisir atau menyebar.

- Nyeri subdiafragma atau nyeri bahu tergantung ada atau tidaknya perdarahan intra-abdominal.

2. Perdarahan \% Perdarahan uterus abnormal (biasanya berupa bercak perdarahan ) terjadi pada 75\% kasus yang merupakan akibat dari lepasnya sebagian desidua.

3. Amenorea \% Amenorea sekunder tidak selalu terdapat dan $50 \%$ penderita KE mengeluhkan adanya spotting pada saat haid yang dinanti sehingga tak jarang dugaan kehamilan hampir tidak ada.

4. Sinkope \% Pusing, pandangan berkunang-kunang dan atau sinkope terjadi pada $1 / 3$ sampai $1 / 2$ kasus KET.

5. "Desidual cast"\% 5 - 10\% kasus kehamilan ektopik mengeluarkan”desidual cast” yang sangat menyerupai hasil konsepsi.

b. Tanda 


\section{Ketegangan abdomen \%}

- Rasa tegang abdomen yang menyeluruh atau terlokalisir terdapat pada $80 \%$ kasus kehamilan ektopik terganggu

- Nyeri goyang servik (dan ketegangan pada adneksa) terdapat pada 75\% kasus kehamilan ektopik.

2. Masa adneksa \% Masa unilateral pada adneksa dapat diraba pada S! sampai $1 \frac{12}{2}$ kasus KE. Kadangkadang dapat ditemukan adanya masa pada cavum Douglassi (hematocele)

3. Perubahan pada uterus \% Terdapat perubahanperubahan yang umumnya terjadi pada kehamilan normal.

\section{Diagnostik}

Semua wanita usia reproduksi dengan nyeri perut, perdarahan uterus, atau kelainan menstruasi harus diuji untuk kehamilan. Setelah kehamilan ditegakkan, lokasi kehamilan biasanya dibuat dengan pemeriksaan USG

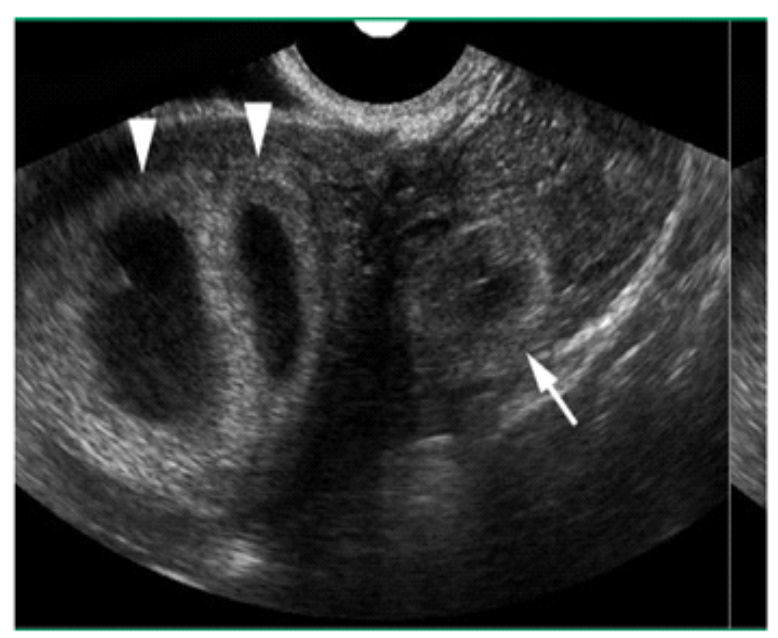

Gambar 1.1 Kehamilan heterotopic pada usia kehamilan 6 minggu, pasien sedang menjalani fertilisasi in vitro. Perhatikan dua kantung rahim gestasional (panah) dan sebuah cincin seperti echogenic massa (panah) di luar rahim dengan gumpalan darah yang berdekatan.

Courtesy of Deborah Levine, MD.
Tanda-tanda sugestif kehamilan heterotopic adalah adanya massa adneksa yang kompleks atau cairan di panggul. Jika dokter memiliki kecurigaan rendah untuk kehamilan heterotopic setelah memvisualisasikan kehamilan intrauterine, kehamilan ektopik dapat palsu berlabel kista korpus luteum. Kehamilan ektopik maju yang mengandung kantung yolk atau tiang janin dengan aktivitas jantung membuat diagnosis lebih mudah untuk dibuat. Adanya cairan bebas dalam perut mungkin merupakan tanda ruptur tuba, tetapi mungkin palsu berlabel ascites berhubungan dengan sindrom hiperstimulasi ovarium. tingkat HCG tidak berguna, karena HCG lebih mencerminkan kehamilan intrauterin.

Evaluasi bedah terus memainkan peran kunci dalam diagnosis kehamilan heterotopic. Beberapa pasien akan hadir dengan sakit parah atau ketidakstabilan hemodinamik yang membuat evaluasi dan perlu perawatan bedah. Pada pasien yang stabil, laparoskopi menawarkan keuntungan dari evaluasi minimal invasif.

Beberapa penelitian terbaru mengatakan bahwa penggunaan Transvaginal Ultrasound untuk diagnosis kehamilan heterotropik sangat membantu terutama pada awal-awal kehamilan. Pada usia kehamilan 5-6 minggu, sensitivitas alat ini hanya 56\%. Jika kehamilan $<6$ minggu, diagnosis dapat dilihat dari adanya tandatanda aktivitas dari denyut jantung bayi. Perancu pada pemeriksaan TVS adalah kantong adneksa dapat terlihat seperti perdarahan corpus luteum ataukista ovarii.

Pemeriksaan Laboratorium biasanya didapatkan penurunan $\mathrm{Hb}$ yang biasanya baru terlihat setelah 24 jam. Selain itu juga didapatkan leukositosis. Jumlah leukosit yang melebihi 20.000 biasa menunjuk pada keadaan terakhir.Pada kehamilan ektopik hampir 100\% menunjukkan pemeriksaan â-hCG positif. Sedangkan, pada kehamilan intrauterin, peningkatan kadar â-hCG meningkat 2 kali lipat setiap dua hari. Akan tetapi tes kehamilan yang negatif tidak menyingkirkan kemungkinan kehamilan ektopik terganggu karena kematian hasil konsepsi dan degenerasi trofoblas menyebabkan produksi HCG menurun dan menyebabkan tes negatif.

Pemeriksaan fisik khusus pada KET adalah Kuldocentesis. Kuldocentesis adalah suatu cara pemeriksaan untuk mengetahui apakah cavum douglasi 
ada darah. Cara ini sangat berguna dalam membantu membuat diagnosis KET. Teknik kuldocentesis dapat dilaksanakan dengan urutan berikut;

- Penderita dibaringkan dalam posisi litotomi.

- Vulva dan vagina di bersihkan dengan larutan antiseptik.

- Spekulum dipasang dan bibir belakang portio dijepit dengan cunam servix; dengan traksi ke depan sehingga fornix posterior tampak.

- Jarum spinal no. 18 ditusukkan kedalam cavum douglasi dan dengan semprit $10 \mathrm{ml}$ dilakukan pengisapan.
- Bila pada pengisapan ditemukan darah maka isinya di semprotkan pada kain kasa dan diperhatikan apakah darah yang dikeluarkan merupakan :

o Darah segar berwarna merah yang dalam beberapa menit akan membeku; darah ini berasal dari arteri atau vena yang tertusuk

o Darah tua berwarna coklat sampai hitam yang tidak membeku, atau yang berupa bekuan kecilkecil; darah ini menunjukan adanya hematokel retrouterina.

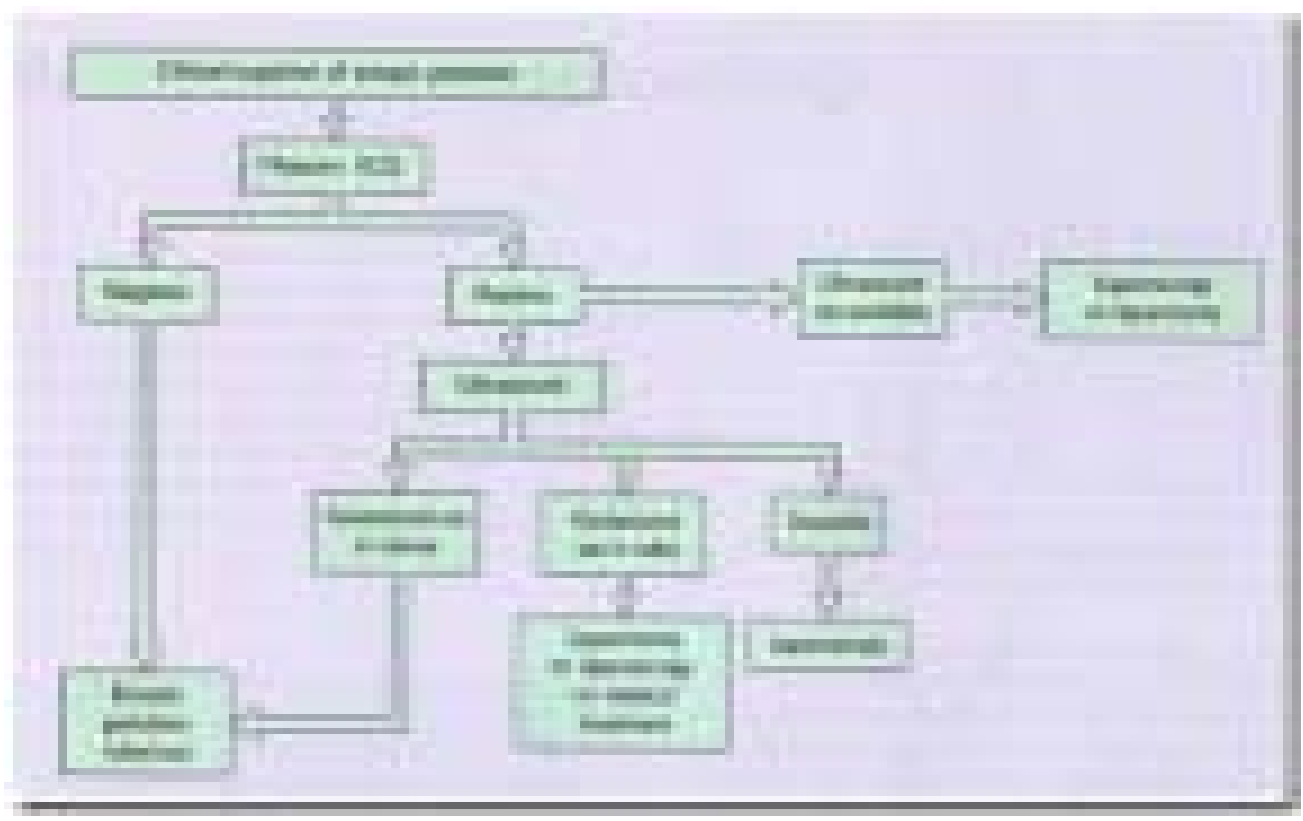

\section{Differential Diagnosis}

Differential diagnosis dari perdarahan uterus dan nyeri pada pasien dengan kehamilan intrauterin harus mencakup aborsi iminen, kehamilan heterotopic, dan pecahnya korpus luteum. Pasien yang menjalani ART, dengan rasa sakit terus-menerus, dan dengan adanya cairan bebas dalam panggul meskipun ada bukti kehamilan intrauterine, harus dievaluasi untuk kehamilan heterotopic. Appendicitis, nefrolitiasis, dan infeksi saluran kemih dapat juga hadir dengan sakit perut di awal kehamilan.

\section{Pengobatan}

Pengobatan dari kehamilan ektopik harus disesuaikan dengan tempat implantasi dan harus memanfaatkan terapi paling invasif untuk mempertahankan kehamilan intrauterine secara bersamaan. Terapi medis sistemik (misalnya, metotreksat) merupakan kontraindikasi pada kehadiran kehamilan intrauterine.

Salpingectomy adalah pendekatan bedah standar dari kehamilan tuba, dan harus menjadi baris pertama pengobatan pada pasien dengan instabilitas hemodinamik atau tanda-tanda lain dari ruptur tuba. 
Pendekatan laparoskopi digunakan jika pasien hemodinamik stabil.

Di tangan seorang ahli, jika kehamilan tidak pecah, maka injeksi lokal ke dalam kantung gestasi di bawah arahan sonografi adalah pengobatan yang efektif. Zat yang digunakan untuk injeksi harus memiliki efektivitas terapi tinggi dengan toksisitas rendah pada kehamilan intrauterin, dan tidak menghasilkan kerusakan yang lama untuk tuba falopi. Dua pilihannya adalah kalium klorida (KCL) dan glukosa hiperosmolar. Sebuah tinjauan literatur dari 11 kasus kehamilan heterotopic diobati dengan KCL injeksi mencatat enam kasus (55 persen) gagal terapi ini dan diperlukan intervensi bedah. Sebuah laporan dari kehamilan serviks diobati dengan KCL injeksi menyebabkan komplikasi pendarahan yang tertunda. Kehamilan intrauterin yang bersamaan dengan kehamilan ektopik harus sebisa mungkian dipertahankan hingga keadaan aterm. Sebuah kehamilan heteropic di bekas luka caesar bersama dengan kehamilan intrauterin berhasil diobati dengan selective embryo reduction melalui cara aspirasi.

Pengguguran janin selektif pada komponen ektopik dilakukan pada beberapa kasuskehamilan heterotopik. Terapi ini dianggap sesuai, namun hanya jika diagnosa dibuat awaldan keadaan hemodinamik pasien stabil.Tiga zat telah digunakan untuk pengguguran janinselektif dalam keadaan seperti itu, termasuk potassium klorida, metotreksat dan glukosahiperosmolar. Lau dan Tulandi meninjau sembilan kasus kehamilan heterotopik interstitialyang diterapi dengan tindakan konservatif maupun teknik pembedahan. Aktivitas jantungditemui dalam semua kasus. Enam diterapi injeksi 0,05-2,0 mmol potassium klorida yangdipandu dengan ultrasonografi ke dalam jantung janin atau pada kantung kehamilan. Salahsatunya diterapi dengan kombinasi potassium klorida dan 12,5 mg metotreksat. Reseksicornual per laparoskopi dilakukan pada dua pasien lainnya. Keseluruhan dari sembilan kasusini tidak memerlukan perawatan lebih lanjut. Tiga kehamilan berakhir dengan aborsi spontandari kehamilan intrauterin yang berjalan secara bersamaan, bagaimanapun, sedangkan enamkasus yang tersisa berakhir dengan persalinan yang sukses. Administrasi sistemik metotreksatmerupakan kontraindikasi dalam keadaan ini karena dapat membahayakan kehamilanintrauterin karena potensi teratogeniknya. Kontroversi baik administrasi lokal darimetotreksat untuk kehamilan ektopik dapat merusak kehamilan intrauterin diselesaikandengan menggunakan potassium klorida atau glukosa hiperosmolar. Penggunaan glukosahiperosmolar dijelaskan oleh Strohmer dan Gjelland, dan kelompoknya dengan hasil yangsukses.

Ada setidaknya satu laporan pada literatur dari aplikasi yang sukses darisalfingosintesis dengan pengenalan dari metotreksat atau potassium klorida kedalam kantungkehamilan ektopik dalam penatalaksanaan dari kehamilan heterotopik jika kehamilan ektopiktidak ruptur dan dapat divisualisasikan secara jelas. Bagaimanapun, pada konsensus secaraumum metode terapi ini masih dalam investigasi pada saat ini dan mungkin hanya dapatdilakukan pada kasus kehamilan heterotopik kornual, interstisial dan ampula dibandingkandengan kehamilan tuba. Secara keseluruhan, sehubungan dengan prognosis dari kehamilanintrauterin, dengan menggunakan terapi pilihan yang berbeda-beda, luaran yang baikdilaporkan pada $50-60 \%$ kasus termasuk, kehamilan tuba, kornual,abdominal, dan implantasiovarium. Pada studi komparatif dan serial kasus oleh Barrenetxea,dkk, pada 80 pasien yangdidiagnosa dengan kehamilan heterotopik dan kehamilan intrauterin yang viabel secarasimultan, 55 kehamilan berlanjut tanpa dijumpai kesulitan sampai aterm (68,75\%). Hal inimenggambarkan sesuatu yang mirip seperti yang dilaporkan oleh Tal, dkk. (66,19\%). Hasilyang lain diperoleh oleh penulis yang lain. Jelaslah, pemberian terapi metotreksat secarasistemik tidak dianjurkan karena dapat menyebabkan ganggguan pada kehamilan intrauterinyang masih berlanjut.

Studi oleh Gyamfi, dkk, menjelaskan kehamilan heterotopik servikal (satu diintrauterin, dan yang lain di bagian atas dari serviks) yang diterapi dengan potassium klorida(3ml) injeksi dan aspirasi dari isi kavum gestasi .Aliran darah, terpisahdari kehamilan yang tersisa yang terlihat dengan doppler pada 19 minggu. Sayangnyajaringan trofoblas masih tersisa, menjadi perdarahan obstetrik pada usia kehamilan 31minggu, dan seterusnya dilakukan histerektomi sesarea darurat dengan janin viabel saatpasien menunggu untuk dilakukan seksio sesarea elektif saat usia kehamilan 32 minggu. 
Komplikasi lain yang mungkin dari teknik ini adalah bahwa difusi dari potassiumklorida pada target kantung amnion , dapat menyebabkan penyebaran ke kantung gestasiyang berdekatan, dan dapat menjadi hal yang berbahaya bagi embrio intrauterin. Ada contohsangat sedikit di mana kedua kehamilan intrauterin dan ekstrauterin berkembang secarabersamaan.

Pengangkatan kehamilan ektopik dengan pembedahan dengan salfingektomi atausalfingostomi adalah merupakan pilihan terapi pada kasus kehamilan heterotopik. Tindakanpembedahan memberikan manfaat yang jelas di atas terapi medis atau konservatif denganmenawarkan hasil yang cepat.Karena sebagian kantung kehamilan berada ektopik pada tuba fallopi, terapi yang palingumum dilakukan adalah salfingektomi, karena kebanyakan pasien didiagnosa pada prosedurpembedahan darurat untuk menentukan penyebab hemoperitoneum. Salfingostomi dan'milking' dari tuba yang terlibat juga pernah dijelaskan.

Kontroversi antara pilihan pembedahan radikal (salfingektomi) (Gambar 6) dibandingkandengan konservatif (salfingostomi) tidak memiliki peranan yang berbeda pada kasus darikehamilan heterotopik mengikuti ART. Tampaknya ada manfaat yang jelas darisalfingektomi dibandingkan dengan pendekatan konservatif dari salfingostomi pada kasus ini.

Bagaimanapun dalam kasus kehamilan ektopik, pilihan untuk terapi konservatif ataulaparoskopi radikal mungkin sulit. Dalam literatur oleh Clausen, tidak ada perbedaan dalamrata rata dari kehamilan intrauterin selanjutnya setelah pembedahan konservatif ataupembedahan radikal untuk kehamilan ektopik tuba. Lebih jauh lagi, beberapa mungkinmemerlukan terapi radikal untuk membuatnya menjadi lebih mudah, dengan demikian dapatmengurangi resiko dari komplikasi yang diobservasi pada salfingostomi.

Louis-Sylvestre, dkk, melaporkan telah melakukan terapi laparoskopi pada 13 orangpasien, 10 dilakukan salfingektomi dan tiga orang dilakukan salfingostomiKemudian, 60\% dari pasien melanjutkan kehamilan intrauterin yang viabelsampai pada saat dilakukan seksio sesarea, dan memiliki luaran yang baik. Di sisi lain, padakasus di mana terjadi ketidakstabilan hemodinamik, tindakan laparotomi lebih dianjurkan

\section{PEMBAHASAN}

Pasien usia 34 tahun hamil 17 minggu, datang dengan keluhan penurunan kesadaran, dan sebelumnya pasien mengeluh nyeri perut setelah BAK. Pasien juga mengalami perdarahan dari jalan lahir 1 minggu yang lalu berlangsung selama 4 hari. Pada pemeriksaan vital sign pasien tersebut tekanan darah 76/43 mmHg, Nadi 97 x/m, Suhu 36.6 C, RR 24 x/m, SaO2 96 \% tanpa O2. Dari pemeriksaan fisik didaatkan pasien mengalami penurunan kesadaran (delirium), pasien juga tampak anemis dan pada pemeriksaan abdomen didapakan distended, defans muscular + , nyeri tekan +, pemeriksaan akral dingin kering pucat. Pada pemeriksaan lokalis teraba benjolan di labia mayor dekstra. Pada pemeriksaan laboratorium didapatkan $\mathrm{Hb}$ 7, Hct 37, Lekosit: 10.400, Trombosit 283.000, HbsAg negatif, Clorida serum 105, Kalium Serum 3,7, Natrium Serum 138, GDA 119, Diffcount 4/1/80/11/4, LED 64/ 86.

Dari data diatas, dapat disimpulkan problem list pada pasien ini yaitu abdominal pain yang bersifat akut, perdarahan pervaginam, anemis, distended, defans muscular, dan juga terdapat syok hemodinamik. Gejalagejala diatas mengarah diagnosis kehamilan heterotropik.

Gejala-gejala diatas sesuai dengan gejala klinis dari kehamilan heterotropik seperti

1. Nyeri \% Nyeri panggul atau abdomen hampir selalu terdapat.

- Nyeri dapat bersifat unilateral atau bilateral ; terlokalisir atau menyebar.

- Nyeri subdiafragma atau nyeri bahu tergantung ada atau tidaknya perdarahan intra-abdominal.

2. Perdarahan \% Perdarahan uterus abnormal (biasanya berupa bercak perdarahan ) terjadi pada $75 \%$ kasus yang merupakan akibat dari lepasnya sebagian desidua. 
3. Ketegangan abdomen

- Rasa tegang abdomen yang menyeluruh atau terlokalisir terdapat pada $80 \%$ kasus kehamilan ektopik terganggu

- Nyeri goyang servik (dan ketegangan pada adneksa) terdapat pada $75 \%$ kasus kehamilan ektopik.

4. Masa adneksa \% Masa unilateral pada adneksa dapat diraba pada S! sampai 1⁄2 kasus KE. Kadang-kadang dapat ditemukan adanya masa pada cavum Douglassi (hematocele)

5. Perubahan pada uterus \% Terdapat perubahanperubahan yang umumnya terjadi pada kehamilan normal.

Untuk memastikan diagnosis pasti dan untuk menyingkirkan diagnosis banding pada pasien ini, perlu dilakukan pemeriksaan penunjang berupa USG kandungan.

Pada hasil USG pasien Ny N didapatkan hasil :

Tampak janin intrauteri , tunggal, gerak (-), Djj (-), Amnion (-), amnion (-), BPD sebesar 4,5 cm sesuai usia kehamilan 19 minggu 4 hari, Tampak cairan / internal bleeding yang banyak. Kesimpulannya adalah kehamilan intra uteri usia sekitar 19 minggu 4 hari , yang mengalami IUFD + internal bleeding yang banyak, curiga ruptur uteri ?.

Pengobatan dari kehamilan ektopik harus disesuaikan dengan tempat implantasi dan harus memanfaatkan terapi paling invasif untuk mempertahankan kehamilan intrauterine secara bersamaan. Salpingectomy adalah pendekatan bedah standar dari kehamilan tuba, dan harus menjadi baris pertama pengobatan pada pasien dengan instabilitas hemodinamik atau tanda-tanda lain dari ruptur tuba. Pendekatan laparoskopi digunakan jika pasien hemodinamik stabil. Pengangkatan kehamilan ektopik dengan pembedahan dengan salfingektomi atausalfingostomi adalah merupakan pilihan terapi pada kasus kehamilan heterotopik. Tindakan pembedahan memberikan manfaat yang jelas di atas terapi medis atau konservatif denganmenawarkan hasil yang cepat.Karena sebagian kantung kehamilan berada ektopik pada tuba fallopi, terapi yang palingumum dilakukan adalah salfingektomi.

Pada kasus ini pilihan yang dikerjakan adalah melakukan laparotomi, dengan kondisi adanya perdarahan intraabdominal yang cukup masif, ditandai dengan kondisi penderita yang mengalami syok hipovolumik. Dan dari hasil laporan operasi didapatkan adanya kehamilan ekstrauterine dan intrauterine dengan usia kehamilan yang berbeda.

Masih menjadi tanda tanya besar adalah bagaimana terjadinya kehamilan intra dan ekstra uterine dalam usia kehamilan yang berbeda.

\section{KESIMPULAN}

Pada kasus yang dialami Ny N dengan keluhan nyeri perut, perdarahan pervaginam, syok hemodinamik, anemis, pada pemeriksaan abdomen didapakan distended, defans muscular +, nyeri tekan +, pemeriksaan akral dingin kering pucat. Pada pemeriksaan lokalis teraba benjolan di labia mayor dekstra serta hasil USG didapatkan kehamilan intra uteri usia sekitar 19 minggu 4 hari, yang mengalami IUFD + internal bleeding yang banyak, curiga ruptur uteri. Sehingga dapat disimpulkan bahwa diagnosis pada pasienini adalah KET + G1 P0000 A000 Uk 19 minggu + IUFD + Syok hypovolemik.

Hal yang masih menjadi pertanyaan besar adalah kejadian rupturnya kehamilan ektopik yang terjadi saat usia kehamilan 17 minggu. Dengan kemungkinan bahwa usia kehamilan antara kehamilan intra dan ekstrauterine ini berbeda.

\section{DAFTAR PUSTAKA}

1. Barrenetxea G, Barinaga-Rementeria L, Lopez de Larruzea A, et al. Heterotopic pregnancy: two cases and a comparative review. Fertil Steril 2007; 87:417.e9.

2. Cheng PJ, Chueh HY, Qiu JT. Heterotopic pregnancy in a natural conception cycle presenting as hematometra. Obstet Gynecol 2004; 104:1195.

3. Clayton HB, Schieve LA, Peterson HB, et al. A comparison of heterotopic and intrauterine-only pregnancy outcomes after assisted reproductive technologies in the United States from 1999 to 2002. Fertil Steril 2007; 87:303. 
4. Goldstein JS, Ratts VS, Philpott T, Dahan MH. Risk of surgery after use of potassium chloride for treatment of tubal heterotopic pregnancy. Obstet Gynecol 2006; 107:506.

5. Habana A, Dokras A, Giraldo JL, Jones EE. Cornual heterotopic pregnancy: contemporary management options. Am J Obstet Gynecol 2000; 182:1264.

6. Hassiakos D, Bakas P, Pistofidis G, Creatsas G. Heterotopic pregnancy at 16 weeks of gestation after in-vitro fertilization and embryo transfer. Arch Gynecol Obstet 2002; 266:124.

7. Hsieh BC, Hwang JL, Pan HS, et al. Heterotopic Caesarean scar pregnancy combined with intrauterine pregnancy successfully treated with embryo aspiration for selective embryo reduction: case report. Hum Reprod 2004; 19:285.

8. Louis-Sylvestre C, Morice P, Chapron C, Dubuisson JB. The role of laparoscopy in the diagnosis and management of heterotopic pregnancies. Hum Reprod 1997; 12:1100.

9.Seeber BE, Barnhart KT. Suspected ectopic pregnancy. Obstet Gynecol 2006; 107:399.

10.Shojai R, Chaumoitre K, Chau C, et al. Advanced combined abdominal and intrauterine pregnancy: a case report. Fetal Diagn Ther 2007; 22:128.

11.Tal J, Haddad S, Gordon N, Timor-Tritsch I. Heterotopic pregnancy after ovulation induction and assisted reproductive technologies: a literature review from 1971 to 1993. Fertil Steril 1996; 66:1. 